\title{
POSTGRADUATE SUPERVISION
}

Patrick Ngulube

University of South Africa, South Africa

E-mail: ngulup@unisa.ac.za

\begin{abstract}
Supervisory practices are fundamental to the production of research in higher education, but these practices are undertheorized and poorly understood. Academia needs to understand and engage with supervisory pedagogies to reinforce their importance in knowledge production and the development of a knowledge society. Using content analysis of master's and doctoral research outputs completed between 2010 and 2016, this case study investigated postgraduate supervision practices in education in South Africa, and their implication for knowledge sharing in context. The findings showed that supervision in education has remained rooted in the classic individualistic model, with team supervision not prevalent. The benefits of team supervision relative to the individualistic model are highlighted. Acknowledgement of the range of competencies of supervisors and the growth of interdisciplinary and multidisciplinary research signals the value of the team supervision model. In addition to improving research support, team supervision also creates communicative spaces and opportunities for knowledge sharing and the development of supervisors.

Keywords: communicative spaces, higher degrees research, knowledge sharing, postgraduate education, postgraduate research supervision, research supervision styles, supervision models
\end{abstract}

\section{Introduction}

Postgraduate education and supervision are central to the acquisition, assimilation and sharing of knowledge. Knowledge production is fundamental to the creation of a knowledge society in support of knowledge-based economies (Fourie-Malherbe et al., 2016; Fullwood et al., 2018). Currently, there are calls for postgraduate education to contribute to the knowledge society and knowledge-based economies (National Planning Commission, 2011; Scott, 2015; Thomson \& Walker, 2010) to respond to both global and local challenges. In recognition of the fact that postgraduate research presents communities with a competitive edge and value-adding processes, the National Development Plan of South Africa (National Planning Commission, 2011) and the Academy of Science [ASSAf] (2010) emphasise the importance of growing the number of postgraduate students in higher education in South Africa to enhance research productivity and to respond to the developmental needs of the country and the knowledge economy.

As creators and communicators of new knowledge, students and supervisors participate actively in the knowledge society and economy. In contributing to the knowledge economy, master's and doctoral students depend greatly on their supervisors for research support. The critical role of supervisors in influencing the success or failure of studies towards research higher degrees has received considerable research attention (Bitzer, 2010; Buttery et al., 2005; Mouton, 2001; Mouton et al., 2015). While postgraduate research depends on effective and efficient supervision, postgraduate research supervision is both undertheorized and poorly 
Patrick NGULUBE. Postgraduate supervision practices in education research and the creation of opportunities for knowledge sharing

PROBLEMS

OF EDUCATION IN THE $21^{\text {st }}$ CENTURY Vol. 79 , No. 2, 202

256

understood (Buttery et al., 2005; Manathunga, 2014; Wisker, 2012). Systematic research to determine the most effective model for postgraduate research is limited (Agné \& Mörkenstam, 2018). In South Africa, postgraduate supervisory pedagogy is "a difficult and seldom explored facet of South African academic life” (Hugo, 2009, p. 703). Academics in South Africa have published limited research on doctoral supervision and supervisors (Mouton et al., 2015). Equally, students in South Africa appear to lack interest in conducting research on postgraduate supervision (Wilkinson et al., 2016). As a result, numerous gaps remain in our understanding of research supervision in this context.

Using content analysis of theses retrieved from the electronic database of the university under review, this case study explored postgraduate supervision practices in education research in South Africa. The research emanated from recognition of the need to understand supervision practices in the selected context and the implications of those practices for knowledge sharing. Therefore, the research aimed to contribute to the literature on supervision models and the potential contribution of these models to knowledge creation and sharing.

\section{Theoretical Background and Conceptual Framework}

\section{Models of Supervision}

Debates relating to postgraduate mentorship have placed supervision arrangements under the spotlight (Lahenius \& Ikävalko, 2014). Supervision and supervision models are notoriously vague and there is no common nomenclature for describing supervision models. For example, Phillips and Pugh (1994) did not differentiate between supervision styles and approaches, while Lee (2012) preferred to refer to supervision models as approaches, and suggested five major conceptual styles, namely functional (directional), enculturation (contractual), critical thinking, emancipation (laissez-faire) and relationship development (pastoral). The terms in brackets are the equivalent supervision management styles described by Gatfield (2005) and Mouton (2001).

The supervision management style or approach determines the roles that the supervisor assumes. These roles include that of adviser, pastor, quality controller, expert guide, coach, and broker (Dietz et al., 2006; Mouton, 2001). Supervision styles and approaches may be employed in both an individual and a team, or a networked context. Doctoral candidates conduct their own research under a single supervisor in a one-to-one relationship in the individualistic or the traditional apprentice-master model (commonly referred to as the traditional British system). By contrast, team or networked supervision (commonly termed the American system) may take two forms. Teamwork may entail a team of two or more supervisors working with one student. Equally, it may involve a team or cohort of students working together on a common project under one supervisor, who may be a principal investigator assisted by a cohort of supervisors (De Lange et al., 2011; Van Biljon \& De Villiers, 2013). Owing to the methodology that was used, which cannot establish whether the student was supervised according to a cohort model, cohort supervision was not considered as an indicator of supervision model for the purposes of this article.

No singular supervision model is better than the other (Guerin et al., 2015). However, evidence suggests that supervision in many countries and disciplines still conforms to the sole supervisor style (Manathunga, 2012). Chiang (2003) and Backhouse (2010) identified the individualistic model as the predominant postgraduate supervision style in the United Kingdom and South Africa respectively. On the other hand, many universities in Australia have moved towards team supervision (Buttery et al., 2005; Robertson, 2017).

Each supervision model has its own challenges, as outlined in Appendix 1 and the disadvantages of collaborative supervision may expose students and supervisors to various risks. Nevertheless, it is possible to manage the risks and tensions that come with co-supervision 
(Watts, 2010) and the benefits of co-supervision far outweigh its disadvantages (Finn, 2005; Lee, 2012). In contrast to team supervision, sole supervision fosters individualism and may be a barrier to knowledge sharing and innovation. Team supervision, on the other hand, creates a communicative space where "learning conversation about supervisory practices" (Wisker, 2012) may take place. Creating communicative spaces helps supervisors to learn certain supervision practices collectively (Carter 2016). The communicative space can enable supervisors to share their vision of quality supervision and supervision practice. Consequently, policy discourses at many universities around the globe are advocating team supervision as best practice (Agné \& Mörkenstam, 2018; Manathunga, 2012).

\section{Conditions Requiring a Student to have Multiple Supervisors}

Despite some of the disadvantages of collaborative supervision outlined in Appendix 1, studies have shown that in certain circumstances it may be necessary for a student to have more than one supervisor. These include the following:

i. Enhancing the experience of the student by bringing in specialists from various disciplines to make inputs on theoretical, methodological, and contentknowledge matters;

ii. ensuring that supervisors monitor one another and watch the student, with the goal of holding the principal supervisors accountable;

iii. facilitating greater access to intellectual and practical support;

iv. bridging the gap created by differences in knowledge, expertise and supervision experience;

v. facilitating communication and oversight when either the student or the supervisor is operating from outside the home faculty, especially in another country;

vi. training of novice supervisors by experienced colleagues;

vii. providing supplementary expertise; and

viii. serving as an academic mobility 'safety net' to ensure that the student does not remain without a supervisor when the supervisor is on extended leave, relocates or retires (Backhouse, 2010; Grossman \& Crowther, 2015; King, 2016; Manathunga, 2012; Olmos-López \& Sunderland, 2017; Phillips \& Pugh, 1994; Pole, 1998; Van Biljon \& De Villiers, 2013).

Some of the eight conditions outlined above manifest themselves in one form or the other in many research supervision environments. The fact that some supervisors opt for sole supervision despite the potential existence of some of these circumstances in their context implies that they are short-changing both the students and themselves, and their ability to draw on collective experiences may be limited if they supervise students in a dyadic manner. This may also undermine their ability to deliver effective supervisory education and best practices, to the detriment of the students' research experience. Individual supervision may lead to supervisors keeping knowledge to themselves, which is detrimental to knowledge sharing and the creation of a learning organisation (Bureš et al., 2011).

\section{Conceptual Framework}

The conceptual framework underpinning this research resulted from drawing together various elements, including components of theories; aspects of frameworks on postgraduate supervision in the extant literature; personal perspectives and experiences of the researcher as a supervisor of postgraduate students; and knowledge of the context of practice. These are some documented strategies for compiling a conceptual framework (Antonenko, 2015; Ngulube, 
Patrick NGULUBE. Postgraduate supervision practices in education research and the creation of opportunities for knowledge sharing

PROBLEMS

OF EDUCATION IN THE $21^{\text {st }}$ CENTURY Vol. 79 , No. 2, 2021

2020). Since the communication dimension and knowledge creation and sharing nuances are evident in postgraduate supervision it seemed logical that communicative action theory (Habermas, 1987) and the theory of knowledge creation (Nonaka \& Takeuchi, 1995) should be used to gain some insights into the supervision arrangements under discussion. Figure 1 depicts the conceptual framework showing the link between knowledge sharing and supervision models in the context of postgraduate supervision in research education.

Communicative action creates a platform for knowledge sharing based on "mutual recognition, reciprocal perspective taking, a shared willingness to consider one's own conditions through the eyes of the stranger, and to learn from one another" (Habermas, 1998, p. 159). Communicative spaces in the context of supervision may be created through working collaboratively and supervisors sharing knowledge and skills. Supervision conducted collectively in teams has the potential to promote knowledge transfer and open dialogue about supervision practices among the team members. Bencic et al., (2009) underscored the importance of teamwork in knowledge sharing and how managing knowledge may give an organisation a competitive edge. Communicative spaces create platforms for managing knowledge and the creation of learning organisations.

Communicative spaces may be equated to the concept of $b a$ in the knowledge creation theory. Knowledge creation theory focuses mainly on $b a$ as the platform for knowledge creation, $b a$ being the context within which knowledge is shared, created and utilised through either faceto-face or online interaction. This interaction has the potential to create and facilitate the use of new knowledge. Nonaka et al. (2000) likened $b a$ to communities of practice where individuals with a common goal share and discuss knowledge, and in so doing improve themselves and their practice.

\section{Figure 1}

Conceptual Framework for Postgraduate Supervision and Knowledge Sharing

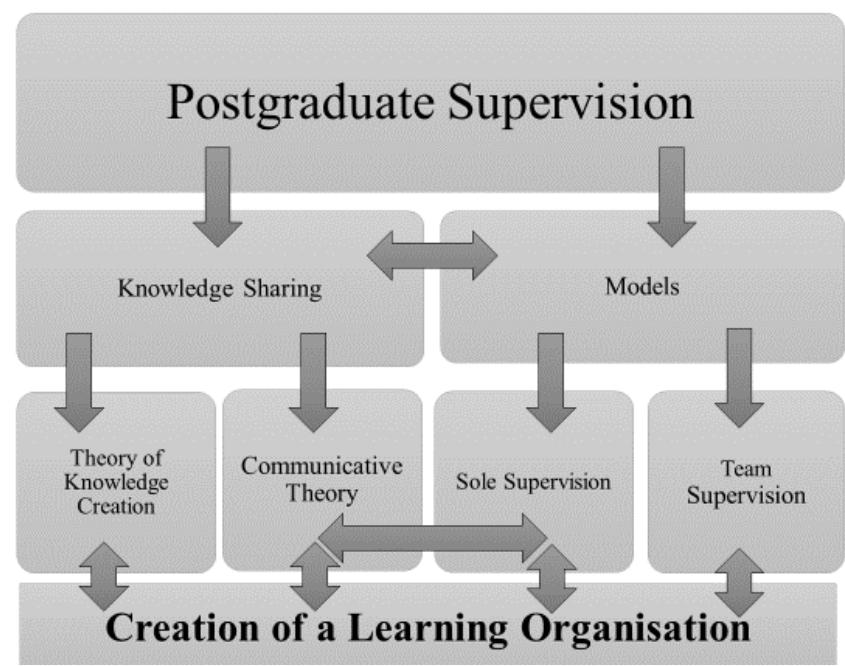

Knowledge sharing, on which the knowledge economy is partly based, depends heavily on the creation of communicative spaces and $b a$. Communicative spaces and $b a$ create an avenue for frank collegial conversations that have the potential to contribute to the members of the team becoming productive and effective supervisors. The two theories referred to above, namely communicative action theory and the theory of knowledge creation, provided insights into the link between creating communicative spaces or $b a$ within the broad context of cosupervision and knowledge sharing. 
Knowledge sharing among postgraduate supervisors may produce graduates that could contribute towards sustaining a knowledge economy. The supervision models adopted by postgraduate supervisors could provide opportunities for such knowledge sharing. Supervision models could determine the extent to which communicative spaces for knowledge creation and sharing are created, and how the supervision load may be shared. However, little is known about supervision practices in education research in South Africa and how these practices could create opportunities for knowledge sharing.

Trend studies may establish the extent to which certain supervision models are prevalent in South Africa and their implication for knowledge sharing. However, there has been limited research on supervision practices in higher education research in South Africa. Hence, this study considered supervision models in the context of supervision practices. In South Africa, studies based on a variety of doctoral supervision styles include those of Backhouse (2010), De Lange et al. (2011), Grossman and Crowther (2015), Lessing (2011) and Manyike (2017). Guerin et al. (2015), Manathunga (2012) and Robertson (2017) examined the practice in Australia, with Dysthe et al. (2006) and Agné and Mörkenstam (2018) conducting similar research in Norway and Sweden, respectively, and Fenge (2012) and Lee (2008) undertaking studies in this area in the United Kingdom. While there have been various studies on postgraduate supervision, not much has been written on supervision models and the opportunities they provide for knowledge sharing.

The main contribution of the research reported on in this article, therefore, lies in its highlighting of the neglected issue of studies on trends in research supervision and the "underexplored" (Olmos-López \& Sunderland, 2017) notion of co-supervision. The research was mainly motivated by Severinsson (2012) who called for more studies on supervisory styles and research outcomes. The article highlights the important link between knowledge sharing and supervision models using communicative action theory and the theory of knowledge creation as a conceptual framework. research:

Building on previous research, the five research questions outlined below guided the

- What are the trends in dissertation and thesis outputs at the selected college?

- Who are the most productive supervisors and what are their supervisory patterns?

- Which is the predominant supervision model in the research outputs that were retrieved from the selected database?

- What are the patterns of supervision by novice supervisors from the selected research outputs?

- To what extent do the prevalent supervision models provide opportunities for knowledge sharing?

\section{Research Methodology}

\section{General Background}

The research employed a case study design. The college that was selected as case study (the College of Education, University of South Africa [Unisa]) was established in 2010 and had grown to become the second largest producer of postgraduate research in the university by 2016, as evidenced by the statistics in the graduation handbooks. It offers 11 master's degrees by full dissertation and doctoral degrees by thesis in 30 areas (Unisa, n.d.).

There are two schools in the college: the School of Educational Studies that consists of the Department of Adult Basic Education, the Department of Educational Foundations, 
Patrick NGULUBE. Postgraduate supervision practices in education research and the creation of opportunities for knowledge sharing

PROBLEMS

OF EDUCATION

IN THE $21^{\text {st }}$ CENTURY Vol. 79 , No. 2, 202

260

the Department of Psychology of Education, the Department of Inclusive Education and the Department of Educational Leadership and Management; and the School of Teacher Education that comprises the Department of Mathematics Education, the Department of Science and Technology Education, the Department of Language Education, Arts and Culture, the Department of Curriculum and Instructional Studies and the Department of Early Childhood Education (Unisa, n.d.).

In addition to vested interest on the part of the researcher, education research was chosen because education has "an ancient lineage" (Lagemann, 1997, p. 5). Furthermore, Wilkinson et al. (2016) confirmed that master's and doctoral studies in South Africa between 2006 and 2016 were concentrated in the same discipline. In this article, master's level research reports were referred to as dissertations, while those at doctoral level were referred to as theses in accordance with the naming convention used by the university under study.

\section{Sample Selection}

Theses and dissertations completed between 2010 and 2016 from the ten departments of the College of Education at the selected university were used in this research. The starting point of 2010 was chosen because that is when the college was established. The cut-off date for the analysis, 2016, exceeded the five-year span for determining the changing trends in scholarly communication recommended in the literature (Stansbury, 2002). The two additional years were included to allow for possible delays in uploading research outputs on the institutional repository within a five-year span. Data was extracted from the Directory of Open Access Repositories (University of Nottingham, 2006-2017). Coursework dissertations were not considered for this research because they are of limited scope and do not place the same demands on a supervisor as a full dissertation, which requires more depth and research.

For the triangulation of data sources, the college website and available graduate booklets were scrutinised during data collection. Although Herman (2017) found the NEXUS database of the National Research Foundation (NRF) to be problematic, the records from the institutional repository were also compared with those in the NEXUS database. The records from the institutional repository proved to be more comprehensive than those in NEXUS.

Following Frick (2016), a final total of 602 retrieved dissertations and theses were subjected to content analysis. Content analysis involves the reduction of text or other media into categories based on coding (Weber, 1990). The sampling scheme for this research was multifaceted. The first phase involved (i) the selection of the research outputs for the education discipline; (ii) determining the format; that is, whether the output was a thesis or dissertation; (iii) scoping the dissertation; (iv) indicating the name(s) of the supervisor(s); and (v) indicating the year of completion. The first sampling phase identified 620 outputs, 367 of which were dissertations, while 253 were theses reviewed. From that, a total of 11 dissertations and seven theses were excluded because either the year of completion, the field of study, or the name(s) of the supervisor(s) were not specified. The number for final analysis was 356 dissertations and 246 theses as illustrated in Table 1. This phase determined the sample that was going to be subjected to further analysis in the second phase.

\section{Instrument and Procedures}

Codes were developed for the second phase of sampling. Developing codes for measuring patterns of scholarly communication is complex and poses difficulties for many researchers. Two coders were involved in coding the variables of supervision trends. The classification criteria used to determine the indicators of supervision trends were: year of completion of the research output; format (i.e., thesis or dissertation); school to which the research output 
Patrick NGULUBE. Postgraduate supervision practices in education research and the creation of opportunities for knowledge sharing

was submitted; year of completion; production language; name of supervisor(s); number of supervisors per research output; academic $\operatorname{rank}(\mathrm{s})$ of the supervisor(s); and subject of the research output. Cohen's kappa ( $\kappa)$ (Cohen, 1960) was used to determine the level of agreement among the coders. Kappa values of 0.40 to 0.60 are considered fair, 0.60 to 0.75 as good, and over 0.75 as excellent (Bakeman \& Gottman, 1997). The intercoder agreement between a postdoctoral fellow who coded 36 dissertations and 25 theses independently and the author was 0.93 . The intercoder agreement for the phase of coding was also excellent at 0.97 . The high level of intercoder agreement showed that the taxonomies chosen for the codes were reliable.

Descriptive statistical methods comprising frequency and percentage were used to summarise the results. The coded data were analysed using Excel ${ }^{\circledR}$. The analysis distinguished theses from dissertations; determined the most productive supervisors and the prevalent supervision models; and established the supervision patterns of novice supervisors.

\section{Research Results}

\section{Trends in Dissertation and Thesis Output at the College}

As shown in Table 1 more dissertations (59.1\%) than theses $(40.9 \%)$ were produced during the period under review. A total of $6.5 \%$ of the dissertations and $2.8 \%$ of the theses were in the Afrikaans language, with the bulk of the research outputs being in the English language. None of the research outputs in Afrikaans were co-supervised. The findings set out in Table 1 revealed that $4.5 \%$ of the dissertations submitted in English were co-supervised, as were 10.2\% of theses. In all, 134 supervisors supervised 356 dissertations, and 99 supervisors supervised 246 theses. Each supervisor supervised approximately three dissertations. The mean production rate for theses was at equilibrium with that of dissertations. The mean may be used cautiously and tentatively to measure performance in the production of research outputs at the college for each supervisor over a rolling period of seven years.

\section{Table 1}

Trends in Research Outputs

\begin{tabular}{ccccccccc}
\hline \multirow{2}{*}{ Year } & \multicolumn{2}{c}{ English } & \multicolumn{2}{c}{ Afrikaans } & \multicolumn{2}{c}{ Co-supervised } & \multicolumn{2}{c}{ Total } \\
\cline { 2 - 9 } & Dissertation & Thesis & Dissertation & Thesis & Dissertation & Thesis & Dissertation & Thesis \\
\hline 2010 & 33 & 21 & 6 & 1 & $3(13.6 \%)$ & 0 & 39 & 22 \\
\hline 2011 & 33 & 22 & 2 & 1 & 0 & $2(8.7 \%)$ & 35 & 23 \\
\hline 2012 & 57 & 32 & 6 & 0 & $3(4.8 \%)$ & $7(11.1 \%)$ & 63 & 32 \\
\hline 2013 & 42 & 42 & 4 & 3 & $3(6.5 \%)$ & $7(15.6 \%)$ & 46 & 45 \\
\hline 2014 & 69 & 39 & 3 & 0 & $2(2.8 \%)$ & $4(10.3 \%)$ & 72 & 39 \\
\hline 2015 & 70 & 48 & 1 & 1 & $3(4.2 \%)$ & $3(6.1 \%)$ & 71 & 49 \\
\hline 2016 & 29 & 35 & 1 & 1 & $2(6.7 \%)$ & $2(5.6 \%)$ & 30 & 36 \\
\hline Totals & 333 & 239 & 23 & 7 & $16(4.5 \%)$ & $25(10.2 \%)$ & 356 & 246 \\
\hline
\end{tabular}

$\mid$\begin{tabular}{l} 
PROBLEMS \\
OF EDUCATION \\
IN THE 21 $21^{\text {st }}$ CENTURY \\
Vol. 79, No. 2, 2021 \\
\hline 261
\end{tabular} 
Patrick NGULUBE. Postgraduate supervision practices in education research and the creation of opportunities for knowledge sharing

PROBLEMS

OF EDUCATION

IN THE $21^{\text {st }}$ CENTURY Vol. 79 , No. 2, 2021

262

\section{Most Productive Supervisors and Their Supervisory Patterns}

The completion rates were difficult to determine from the gathered data. What was clear, however, was that at least a certain number of students had completed their research programmes. A supervisor was regarded as productive if, during the period under review, they had supervised more than three students, which was the mean score of the collected data. The most productive supervisors and the aspects they supervised are reflected in Tables 2 and 3.

The initial intention was to designate the 10 most successful supervisors by means of letters of the alphabet, namely A, B, C, D, E, F, G, H, I and J, but K and L had to be added because supervisors $\mathrm{J}, \mathrm{K}$ and $\mathrm{L}$ had each supervised five students. Consequently, there were 12 most successful supervisors instead of 10 in the end. While these designations were applied in the case of supervisors at doctoral degree level (Table 2), the following notations were assigned to the most successful supervisors at master's degree level: A1, B1, C1, D1, E1, F1, G1, H1, I1, J1, K1 and L1 (Table 3). The year in brackets in the first columns of Tables 2 and 3 indicates when the supervisor had attained the rank of professor, irrespective of whether it was an associate or full professorship. A range of dates, for example in the case of supervisors C, E, $\mathrm{B} 1[\mathrm{~K}]$, and so on, designate the period during which the supervisors were not yet professors, but were supervising at doctoral and master's levels. This category of supervisors produced most of the doctoral degrees (refer Table 4).

Table 2

Most Productive Supervisors at Doctoral Level

\begin{tabular}{|c|c|c|c|c|c|}
\hline \multirow{2}{*}{ Supervisor } & \multirow{2}{*}{ School } & \multirow{2}{*}{ Aspect supervised } & \multirow{2}{*}{$\begin{array}{l}\text { Number of } \\
\text { students }\end{array}$} & \multicolumn{2}{|c|}{ H-index } \\
\hline & & & & Scopus & Google \\
\hline$A(2010)$ & $\begin{array}{l}\text { Educational } \\
\text { Studies }\end{array}$ & $\begin{array}{l}\text { Psychology of Education (5), Education } \\
\text { Management (2), Inclusive Education } \\
\text { (1), Socio-education (1) }\end{array}$ & 9 & $3\left(1^{* *}\right)$ & 11 \\
\hline$B(2010)$ & $\begin{array}{l}\text { Educational } \\
\text { Studies }\end{array}$ & $\begin{array}{l}\text { Comparative Education (1), Socio- } \\
\text { education (3), Education Management } \\
\text { (4) }\end{array}$ & 8 & $-\left(2^{\star \star}\right)$ & 17 \\
\hline $\begin{array}{l}C(2011- \\
2012)\end{array}$ & $\begin{array}{l}\text { Educational } \\
\text { Studies }\end{array}$ & Education Management (8) & 8 & $4\left(2^{* *}\right)$ & 18 \\
\hline$D(2011)$ & $\begin{array}{l}\text { Educational } \\
\text { Studies }\end{array}$ & Education Management (7) & $\begin{array}{l}7\left(1^{*}\right) \text { with a } \\
\text { professor }\end{array}$ & - & \\
\hline $\begin{array}{l}E(2010- \\
2013)\end{array}$ & Teacher Education & $\begin{array}{l}\text { Didactics (1), Curriculum Studies (5), } \\
\text { Education Management (1) }\end{array}$ & $\begin{array}{l}7\left(1^{*}\right) \text { with a } \\
\text { professor }\end{array}$ & $2\left(0^{* *}\right)$ & 7 \\
\hline$F(2011)$ & Teacher Education & $\begin{array}{l}\text { Didactics (1), Curriculum Studies (5), } \\
\text { Education Management (1) }\end{array}$ & 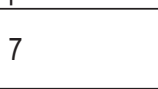 & $1\left(1^{* *}\right)$ & 7 \\
\hline G (2010) & Teacher Education & Educational Leadership (7) & $\begin{array}{l}7\left(2^{*}\right) \text { with } \\
\text { doctorate } \\
\text { holders }\end{array}$ & - & 4 \\
\hline H (2010) & $\begin{array}{l}\text { Educational } \\
\text { Studies }\end{array}$ & $\begin{array}{l}\text { Guidance and Counselling (4), } \\
\text { Psychology of Education (3) }\end{array}$ & 7 & $-\left(1^{* *}\right)$ & 3 \\
\hline $\begin{array}{l}\text { I (2010- } \\
2011)\end{array}$ & $\begin{array}{l}\text { Educational } \\
\text { Studies }\end{array}$ & Education Management (6) & 6 & $6\left(1^{* *}\right)$ & 6 \\
\hline $\mathrm{J}(2010)$ & Teacher Education & $\begin{array}{l}\text { Didactics (1), Curriculum Studies (1), } \\
\text { Education Management (1), Natural } \\
\text { Science (2) }\end{array}$ & $\begin{array}{l}5\left(1^{*}\right) \text { with a } \\
\text { professor }\end{array}$ & $6\left(3^{* *}\right)$ & 9 \\
\hline $\begin{array}{l}K(2010- \\
2012)\end{array}$ & $\begin{array}{l}\text { Educational } \\
\text { Studies }\end{array}$ & $\begin{array}{l}\text { Socio-education (1), Philosophy of } \\
\text { Education (1), Education Management } \\
\text { (3) }\end{array}$ & $\begin{array}{l}5\left(1^{*}\right) \text { with a } \\
\text { professor }\end{array}$ & $2\left(0^{* *}\right)$ & 6 \\
\hline$L(2010)$ & $\begin{array}{l}\text { Educational } \\
\text { Studies }\end{array}$ & $\begin{array}{l}\text { Education Management (4), } \\
\text { Comparative Education (1) }\end{array}$ & 5 & $3\left(0^{\star *}\right)$ & 9 \\
\hline
\end{tabular}

Notes. *Numbers in brackets indicate the instances of co-supervision and total number students involved

*** Web of Science H-index in round brackets 
Patrick NGULUBE. Postgraduate supervision practices in education research and the creation of opportunities for knowledge sharing

PROBLEMS

OF EDUCATION

IN THE $21^{\text {st }}$ CENTURY

Vol. 79, No. 2, 2021

Eight of the supervisors in Table 2 had guided more students than the mean graduation rate of 6.75 graduates. Five of the 12 successful supervisors co-supervised their students. Only supervisor $\mathrm{J}_{1}[\mathrm{G}]$ co-supervised with the holder of either a doctorate or a master's degree, as indicated by the numbers in the round brackets in the fourth column of Tables 2 and 3 . The most productive supervisors at doctoral level have a relatively high $h$-index with double-digit figure (refer Table 2).

Table 3

Most Successful Supervisors at Master's Level

\begin{tabular}{|c|c|c|c|c|c|}
\hline \multirow{2}{*}{ Supervisor } & \multirow{2}{*}{ School } & \multirow{2}{*}{ Aspect supervised } & \multirow{2}{*}{$\begin{array}{l}\text { Number of } \\
\text { students }\end{array}$} & \multicolumn{2}{|c|}{ H-index } \\
\hline & & & & Scopus & Google \\
\hline$A_{1}[H](2010)$ & $\begin{array}{l}\text { Educational } \\
\text { Studies }\end{array}$ & Guidance and Counselling (10) & 10 & $-\left(1^{* \star}\right)$ & 3 \\
\hline $\begin{array}{l}B_{1}[K] \\
(2010-2012)\end{array}$ & $\begin{array}{l}\text { Educational } \\
\text { Studies }\end{array}$ & Education Management (9) & 9 & $2\left(0^{* \star}\right)$ & 6 \\
\hline$C_{1}(2012)$ & $\begin{array}{l}\text { Teacher } \\
\text { Education }\end{array}$ & $\begin{array}{c}\text { Didactics (1), Education } \\
\text { Management (5), Curriculum Studies } \\
\text { (3) }\end{array}$ & 9 & $3\left(2^{\star *}\right)$ & 7 \\
\hline$D_{1}(2010-2014)$ & $\begin{array}{l}\text { Teacher } \\
\text { Education }\end{array}$ & $\begin{array}{c}\text { Adult Education (6), Curriculum } \\
\text { Studies (1) }\end{array}$ & 7 & - & 1 \\
\hline$E_{1}(2013-2014)$ & $\begin{array}{l}\text { Teacher } \\
\text { Education }\end{array}$ & Natural Science (7) & 7 & $1\left(0^{\star *}\right)$ & 1 \\
\hline $\mathrm{F}_{1}(2010-2012)$ & $\begin{array}{l}\text { Educational } \\
\text { Studies }\end{array}$ & Education Management (7) & 7 & - & 0 \\
\hline $\begin{array}{l}G_{1}(2012- \\
2012)\end{array}$ & $\begin{array}{l}\text { Teacher } \\
\text { Education }\end{array}$ & $\begin{array}{l}\text { Inclusive Education (1), Natural } \\
\text { Science (3), Socio-education (1), } \\
\text { Inclusive Education (1) }\end{array}$ & 6 & - & 1 \\
\hline $\mathrm{H}_{1}(2012)$ & $\begin{array}{l}\text { Teacher } \\
\text { Education }\end{array}$ & Inclusive Education (6) & 6 & $2\left(0^{\star *}\right)$ & 8 \\
\hline $\mathrm{I}_{1}(2010-2011)$ & $\begin{array}{l}\text { Teacher } \\
\text { Education }\end{array}$ & $\begin{array}{l}\text { Inclusive Education (3), Education } \\
\text { Management (2), Curriculum Studies } \\
\text { (1) }\end{array}$ & 6 & 1 & 6 \\
\hline $\mathrm{J}_{1}[\mathrm{G}](2010)$ & $\begin{array}{l}\text { Teacher } \\
\text { Education }\end{array}$ & $\begin{array}{l}\text { Education Management (3), Adult } \\
\text { Education (2), Inclusive Education } \\
\text { (1) }\end{array}$ & $\begin{array}{c}6(1 \#) \\
\text { supervised } \\
\text { with the } \\
\text { holder of } \\
\text { a master's } \\
\text { degree }\end{array}$ & - & 4 \\
\hline $\begin{array}{l}\mathrm{K}_{1}[\mathrm{C}] \\
(2011-2012)\end{array}$ & $\begin{array}{l}\text { Educational } \\
\text { Studies }\end{array}$ & Education Management (6) & 6 & $4\left(2^{* \star}\right)$ & 18 \\
\hline $\mathrm{L}_{1}[\mathrm{~A}](2010)$ & $\begin{array}{l}\text { Educational } \\
\text { Studies }\end{array}$ & $\begin{array}{c}\text { Education Management (2), } \\
\text { Psychology of Education (1), Socio- } \\
\text { education (1), Inclusive Education } \\
\text { (1) }\end{array}$ & 5 & $3\left(1^{* \star}\right)$ & 11 \\
\hline
\end{tabular}

Notes. \#Number in brackets indicates the total number of students co-supervised

*** Web of Science H-index in round brackets

\section{Predominant Graduate Supervision Practices}

Sole supervision practices were prevalent among the majority of the most successful supervisors. Sole supervision was also predominant all round, with a score of $89.8 \%$ for theses 
Patrick NGULUBE. Postgraduate supervision practices in education research and the creation of opportunities for knowledge sharing

PROBLEMS

OF EDUCATION

IN THE $21^{\text {st }}$ CENTURY Vol. 79 , No. 2, 2021

and $95.5 \%$ for dissertations as illustrated in table 3 and 2 respectively. Such a supervision environment is likely to reduce the creation of formal communicative spaces between supervisors and may have created a barrier to knowledge sharing.

\section{Patterns of Supervision by Novice Supervisors}

Supervisors who had master's degrees or PhDs but had not attained the rank of professor were considered novice supervisors. Novice supervisors were new supervisors who have not yet mastered the art of supervision. Patterns of supervision by holders of master's and doctoral degrees in the College are outlined in Table 4. A total of $80 \%$ of master's holders supervised master's students on their own. The situation was similar at PhD level as $83.3 \%$ of doctoral candidates were produced by $\mathrm{PhD}$ holders without the benefit of co-supervision. Cumulatively, that accounted for $14.6 \%$ of doctorates that were supervised by novices. In 2015 , two $\mathrm{PhD}$ holders co-supervised a doctorate.

Table 4

Patterns of Supervision by Holders of Master's and Doctoral Degrees with Limited Experience

\begin{tabular}{|c|c|c|c|}
\hline Year & $\begin{array}{l}\text { Doctorates produced by } \\
\text { doctoral degree holders } \\
\qquad(\mathrm{N}=246)\end{array}$ & $\begin{array}{l}\text { Master's degrees produced } \\
\text { by doctoral degree holders } \\
\qquad(\mathrm{N}=356)\end{array}$ & $\begin{array}{c}\text { Master's degrees } \\
\text { produced by master's } \\
\text { degree holders }(\mathrm{N}=356)\end{array}$ \\
\hline 2010 & 3 & $\begin{array}{c}10 \text { (1 co-supervised with a } \\
\text { professor) }\end{array}$ & - \\
\hline 2011 & $\begin{array}{l}\text { 4(1) co-supervised with a } \\
\text { professor }\end{array}$ & $\begin{array}{c}13 \text { (1 co-supervised by doctoral } \\
\text { degree holders) }\end{array}$ & 1 \\
\hline 2012 & $\begin{array}{l}\text { 7(2) co-supervised with a } \\
\text { professor }\end{array}$ & $\begin{array}{c}17 \text { (2 co-supervised with a } \\
\text { professor) }\end{array}$ & 4 \\
\hline 2013 & $\begin{array}{l}\text { 9(2) co-supervised with a } \\
\text { professor }\end{array}$ & 26 & $\begin{array}{c}\text { 3(1) co-supervised with a } \\
\text { professor }\end{array}$ \\
\hline 2014 & 6 & 14 & $\begin{array}{l}\text { 4(1) co-supervised with a } \\
\text { doctoral degree holder }\end{array}$ \\
\hline 2015 & $\begin{array}{c}6(1) \text { co-supervised with a } \\
\text { professor (2 co-supervised } \\
\text { with doctoral degree holders } \\
\text { exclusively) }\end{array}$ & $\begin{array}{l}21 \text { (1 co-supervised with a } \\
\text { professor) (1 co-supervised with } \\
\text { doctoral degree holders) }\end{array}$ & $\begin{array}{l}\text { 1(1) co-supervised with } 2 \\
\text { doctoral degree holders) }\end{array}$ \\
\hline 2016 & 1 & $\begin{array}{c}12 \text { (1 co-supervised with a } \\
\text { professor) }\end{array}$ & 2 \\
\hline Total & $36(6)$ & $113(6)$ & $15(3)$ \\
\hline $\begin{array}{l}\% \text { of research } \\
\text { outputs produced } \\
\text { with co- } \\
\text { supervision }\end{array}$ & $16.7 \%$ & $5.3 \%$ & $20 \%$ \\
\hline
\end{tabular}

Notes. Numbers in round brackets indicate the number of research outputs that were co-supervised

\section{Discussion}

There were more master's dissertations than theses, partly due to the fact that master's programmes feed into doctoral programmes. Although, there are 11 official languages in South Africa, many research outputs were either in English or Afrikaans. The submission of theses and 
dissertations in languages other than these two in South Africa is a trend worth watching. The implication is that transformation in relation to the use of the language of knowledge production has not taken root in the college despite the fact that, nowadays, there is a move towards the promotion of the other official languages in the production of knowledge at this level as a result of, among other things, the move to decolonise the curriculum. For instance, the University of Fort Hare (Feni, 2018) conferred one of the first doctoral degrees on a candidate who submitted her dissertation written in isiXhosa, one of the 11 official languages of South Africa.

One would have expected the high performers in research supervision to be prolific authors as a mark of the research prowess evidenced in all the major indices, including Google Scholar, Scopus, and the Web of Science. Each successful supervisor's research outputs were quantified (i.e., research impact in relation to publications). High citation metrics may suggest that the academic has had a significant impact on the relevant field, but Harzing (2007) cautioned that that may not always be the case for a variety of reasons, including the avenues that the authors used to disseminate their research outputs. The Google Scholar H-index seems to suggest that the successful supervisors were making a fairly significant impact on their field. However, as a result of the methodological limitations of the research, the international impact made by the supervisors was undetermined. The University of Cape Town, one of the highest-ranking universities in South Africa, requires that a supervisor have a $\mathrm{PhD}$ and be an expert in their field with an international publication record (De Gruchy \& Holness, 2007). An examination of the relationship between being a successful supervisor and having a significant impact on the field may be instructive.

There were 12 productive supervisors, but fewer than half of them co-supervised. Successful supervisors have the potential to share knowledge with their peers and mentor novices if a communicative space such as the one provided by collaborative supervision is created. It is evident that supervision at the college remains rooted in the traditional apprenticemaster model. This differed from the situation in the United Kingdom, where Olmos-López and Sunderland (2017) found co-supervision to be a common practice. Backhouse (2010) found that styles for supervision training of doctoral degree candidates in South Africa were not uniform, although the individualist structure was prevalent. She concluded that the tendency towards cosupervision or a lack of it could not be attributed to any one discipline but is largely dependent on the way that research higher degrees are funded, the number of students to be supervised and the workloads of supervisors (Backhouse, 2010 21). Some studies concluded that team supervision was more prevalent in the natural sciences where researchers are generally linked to larger research projects than in social sciences (Chiang, 2003; Fenge, 2012; Grossman \& Crowther, 2015). However, owing to its scope and limitations, this research was unable to provide any information relating to differences between supervision in the social and natural sciences.

It is argued that the recognition and reward systems prevailing in South Africa do not seem to support team supervision. Many postgraduate supervisors at South African universities receive research incentives for each postgraduate student delivered, as provided for by the South African Research Funding Framework of 2003 (Mouton et al., 2015). The number of points awarded for promotion based on supervision is divided by the number of supervisors who were involved in supervising a student to completion. For instance, if three supervisors were involved in producing a postgraduate output, each would be awarded a third of the overall score. Someone aspiring to become an associate or full professor would therefore rather supervise a student alone than risk their scores being affected. The reasons why noteworthy co-supervision is not practised at the college may be a variable of the research-output incentive system. However, based on the methodology that was used, that assumption could not be made conclusively. Further research may assist in this regard. Furthermore, funding dynamics are known to have had profound effects on supervision pedagogy in New Zealand (McCallin \& 
Patrick NGULUBE. Postgraduate supervision practices in education research and the creation of opportunities for knowledge sharing

PROBLEMS

OF EDUCATION IN THE $21^{\text {st }}$ CENTURY Vol. 79, No. 2, 2021

266

Nayar, 2012). It may also be a barrier to knowledge sharing (Fullwood et al., 2018). Hence, the existing incentive system is more likely to create an academic culture of individualism.

Individualism promotes the sole supervision model. The dyadic supervision model creates a limited environment for fostering teamwork, collaboration, and networking. It does not create a platform for sharing knowledge, as each supervisor is preoccupied with their "secret garden" (Grossman \& Crowther, 2015). By contrast, the team supervision environment creates a communicative space, or $b a$, that facilitates knowledge construction and sharing through association and interaction. Although the creation of communicative spaces, or $b a$, cannot guarantee the creation of a knowledge-sharing culture, there is evidence that such opportunities lead to a flow of knowledge and experiences, and encourage knowledge sharing among academics (Fullwood et al., 2018).

The environment created by team supervision empowers supervisors to work collaboratively in developing networks through which knowledge is shared. Knowledge sharing leads to the personal development of the individual, a phenomenon that is central to learning within societies and the learning organisation. Knowledge sharing at the college that was investigated may facilitate innovation in supervision practices and make supervisors effective. Effective supervisors enable their students to produce high-quality research, complete their studies on time, and disseminate results widely. They also prepare their students for careers in research (Phillips \& Pugh, 1994). If supervisors are to improve, their knowledge needs to deepen. Knowledge sharing has the potential to provide such an opportunity. Knowledge sharing can be a powerful tool for academic development among novice supervisors.

The sole supervision model followed predominantly at the college also has implications for novice supervisors. Supervision presents very real challenges for novice supervisors in particular (Carter, 2016). Experienced supervisors should support novice supervisors so that they could eventually become effective supervisors. Co-supervision assists beginning supervisors in becoming familiar with the pedagogy of graduate supervision. Moreover, collaborative supervision enables novices to learn from other colleagues. Newcomers should not be left to reinvent the wheel. "Rather they need a practicum, with supervisors who can demonstrate, advise, observe performance, detect errors of application, and point out correct responses." (Leonard, 2001, p. 42).

Grossman and Crowther (2015) recommended that novice supervisors should co-supervise at least three theses with three different mentors with good track records before supervising on their own. Manyike (2017) also underscored the need for experienced supervisors to share their knowledge with novice academics. This knowledge-transfer mechanism may be beneficial to many universities in South Africa where supervision capacity is reported to be inadequate as postgraduate candidature is rising steeply (Grossman \& Crowther, 2015). Supervisors with a master's degree who co-supervised with a doctoral degree holder or a professor had someone to support them as they learnt the art of supervision. The same applied to the doctoral degree holders who supervised with professors. It is doubtful whether it is beneficial for two doctoral degree holders to supervise on their own without a senior colleague, as happened in 2015. While the situation of having two doctoral holders supervising on their own has the potential for creating a space for knowledge sharing, it may be useful for novices to learn from experienced supervisors. Supervising with a senior colleague provides the novice supervisor with an opportunity for capacity development, which partly explains why collaborative supervision is also regarded as an important part of staff development (Olmos-López \& Sunderland, 2017). Novice supervisors would then be able to compare what worked for them as postgraduate students with the knowledge and skills they would be gaining from the giants in their fields.

It is mandatory in some countries to receive additional training in research supervision before one may supervise postgraduate students, even if one holds a doctorate (Taylor \& Beasley, 2005; Wisker, 2012). In South Africa, there seems to be no formal policy governing the support 
that new supervisors should receive through mentoring and/or co-supervision. Lessing (2011) confirmed that $84 \%$ of the lecturers at Unisa's College of Education had acquired supervision knowledge through workshops; informal and formal mentoring; and discussion with colleagues. The Higher Education Qualifications Framework seems to reinforce the perceived lack of a need for mentoring arrangements, especially for doctorates, stating that: "A graduate must be able to supervise and evaluate the research of others in the area of specialisation concerned." (Department of Education, 2007). However, studies have shown that simply having a doctoral degree is insufficient to enable one to be an effective supervisor (Grossman \& Crowther, 2015; Taylor \& Beasley, 2005). Where formal training is not provided, as is the case at Unisa, it is apparent that beginning supervisors are thrown in at the deep end and teach themselves the rules of the pedagogy of graduate supervision.

Unisa requires those supervising doctoral studies to have a doctorate: "Supervisors of doctoral candidates must themselves hold a Doctorate and have a research record that is deemed acceptable by the College for the appointment." (University of South Africa, 2017, p. 8). The interpretation of what constitutes a research record has been left fluid. That leaves each college to use its discretion. The master's and doctoral procedures of Unisa do not say anything about novice supervisors supervising in collaboration with an experienced colleague, as stipulated in other codes of practice such as that of the University of Edinburgh (University of Edinburgh, 2017).

\section{Conclusions and Implications}

The traditional master-apprenticeship epistemology characterised by solo supervision was shown to be more prevalent than co-supervision at the college. Although there is no singular correct model of supervision, the traditional model of one supervisor working on their own with one student does not create a communicative space where supervisors are able to collaborate and share knowledge. Although co-supervision is not without its problems, future doctoral programmes should consider team supervision. Team supervision has the potential to create a collaborative culture in supervision practice and develop pedagogical innovations to the current practice, which could promote the development of professional learning communities in a learning organisation.

The findings presented in this study may have implications for knowledge sharing and the development of a knowledge economy. The potential of knowledge sharing should be considered when deciding on a preferred supervision model, either in policy or in practice. Alternative supervision models have the potential to draw on the collective experience of a supervision team and best practices. That may lead to the increased effectiveness of supervision in higher education and, by implication, an improvement in the quality of graduate students produced. The research reported on this article was based on an investigation of postgraduate supervision at a higher education institution in South Africa. Hence, it may add to the existing understanding of supervision models and the potential opportunities they provide for sharing knowledge and creating a learning organisation.

Lastly, the methodological limitation of this study must be acknowledged. The study was based on a single case, and only one methodology was used. Consequently, the significance of the results cannot be supported. The context and method, furthermore, limit the generalisation of the findings. This article, therefore, provides only a preliminary examination of the phenomenon, and there is room for further studies using other methodologies like mixed methods research. For instance, no conclusion could be made about the extent to which informal supervision arrangements were employed at the college. Informal supervision arrangements, when effectively used, may bridge any shortcomings in the expertise of the supervisor and lessen the supervisory burden.

\author{
PROBLEMS \\ OF EDUCATION \\ IN THE $21^{\text {st }}$ CENTURY \\ Vol. 79, No. 2, 2021 \\ 267
}


Patrick NGULUBE. Postgraduate supervision practices in education research and the creation of opportunities for knowledge sharing

PROBLEMS

OF EDUCATION IN THE $21^{\text {st }}$ CENTURY Vol. 79, No. 2, 2021

However, the case study presented in this article provided insights that may apply to postgraduate supervision in a context that follows the European or United Kingdom doctoral model. The work should be extended to multiple colleges at the university and other higher education institutions to provide a comprehensive picture of supervisory pedagogies in the country and across countries and regions. The results of this research support the salience of communicative action theory and the theory of knowledge creation in explaining knowledge sharing in the context of research supervision. Team supervision can create communicative spaces and $b a$ for knowledge sharing and developing a learning organisation.

\section{References}

Academy of Science in South Africa (ASSAf). (2010). The PhD study: An evidence-based study on how to meet the demands for high-level skills in an emerging economy. ASSAf.

Agné, H., \& Mörkenstam, U. (2018). Should first-year doctoral students be supervised collectively or individually? Effects on thesis completion and time to completion. Higher Education Research \& Development, 37(4), 669-682. https://doi.org/10.1080/07294360.2018.1453785

Antonenko, P. D. (2015). The instrumental value of conceptual frameworks in educational technology research. Educational Technology Research Development, 63(1), 53-71.

Backhouse, J. (2010). Patterns of practice in South African doctoral education: An empirical study. Acta Academica Supplementum, 1, 1-22. https://journals.ufs.ac.za/index.php/aa/article/view/1275

Bakeman, R., \& Gottman, J. M (1997). Observing interaction - An introduction to sequential analysis. Cambridge University Press.

Bencsik, A., Noszkay, E., \& Marosi, I. (2009). Teamwork in education. Problems of Education in the 21st Century, 10, 9-24. http://www.scientiasocialis.lt/pec/node/185

Bitzer, E. (2010). Postgraduate research supervision: More at stake than research training. Acta Academica Supplementum, 1, 23-56.

Bureš, V., Griffin, D., Hackett, D., Kročitý, P., \& Kubička, E. (2011). Rethinking of knowledge management introduction at teaching universities: The framework development. Problems of Education in the 21st Century, 32, 33-46. http://www.scientiasocialis.lt/pec/files/pdf/vol32/3346.Bures Vol.32.pdf

Buttery, E. A., Richter, E. M., \& Filho, W. L. (2005). An overview of the elements that influence efficiency in postgraduate supervisory practice arrangements. International Journal of Educational Management, 19(1), 7-26.

Carter, J. W., Enyedy, K. C., Goodyear, R. K., Arcinue, F., \& Puri, N. N. (2009). Concept mapping of the events supervisees find helpful in group supervision. Training and Education in Professional Psychology, 3(1), 1-9.

Carter, S. (2016). Supervision learning as conceptual threshold crossing: When supervision gets 'medieval'. Higher Education Research \& Development, 35(6), 1139-1152. https://doi.org/10.1080/07294360.2016.1160875

Chiang, K-H. (2003). Learning experiences of doctoral students in UK universities. The International Journal of Sociology and Social Policy, 23(1/2), 4-32.

Cohen, J. (1960). A coefficient of agreement for nominal scales. Educational and Psychological Measurement, 20, 37-46.

De Gruchy, J. W., \& Holness, L. (2007). The emerging researcher: Nurturing passion, developing skills, producing output. University of Cape Town Press.

De Lange, N., Pillay, G., \& Chikoko, V. (2011). Doctoral learning: A case for a cohort model of supervision and support. South African Journal of Education, 31(1), 15-30.

Department of Education (DoE). (2007). The higher education qualifications framework (HEQF). Government Gazette (No. 303530, Vol. 508). Government Printing Works.

Dietz, A. J., Jansen, J. D., \& Wadee, A. A. (2006). Effective PhD supervision and mentorship: A workbook based on experiences from South Africa and the Netherlands. Unisa Press \& Rozenberg Publishers.

Dysthe, O., Samara, A., \& Westrheim, K. (2006). Multivoiced supervision of master's students: A case study of alternative supervision practices in higher education. Studies in Higher Education, 31(3), 299-318.

Fenge, L. (2012). Enhancing the doctoral journey: The role of group supervision in supporting collaborative learning and creativity. Studies in Higher Education, 37(4), 401-414. 
Patrick NGULUBE. Postgraduate supervision practices in education research and the creation of opportunities for knowledge sharing

Feni, L. (2018, October 23). Doctor feels good after historic IsiXhosa PhD at Fort Hare University. Daily Dispatch. https://www.timeslive.co.za/news/south-africa/2018-10-23-doctor-feels-good-afterVol. 79, No. 2, 2021 historic-isixhosa-phd-at-fort-hare-university/

Finn, J. A. (2005). Getting a PhD: An action plan to help manage your research, your supervisor, and your project. Routledge.

Fourie-Malherbe, M., Aitchison, C., Bitzer, E., \& Albertyn, R. (2016). (Re)Considering postgraduate education and supervision in the knowledge society. In Fourie-Malherbe, M., Albertyn, R., Aitchison, C. \& Bitzer, E. (Eds.), Postgraduate supervision: Future foci for the knowledge society (pp. 1-12). SUN MeDIA.

Frick, L. (2016). PhD by publication: an institutional analysis. In Fourie-Malherbe, M., Albertyn, R., Aitchison, C. and Bitzer, E. (Eds.), Postgraduate supervision: Future foci for the knowledge society (pp. 299-312). SUN MeDIA.

Fullwood, R., Rowley, J., \& McLean, J. (2018). Exploring the factors that influence knowledge sharing between academics. Journal of Further and Higher Education, https://doi.org/10.1080/030987 7X.2018.1448928

Gatfield, T. J. (2005). An investigation into PhD supervisory management styles: Development of a dynamic conceptual model and its managerial implications. Journal of Higher Education Policy and Management, 27(3), 311-325.

Grossman, E. S., \& Crowther, N. J. (2015). Co-supervision in postgraduate training: Ensuring the right hand knows what the left hand is doing. South African Journal of Science, 111(11/12). Article 2014-0305, 8 pages. http://dx.doi.org/10.17159/sajs.2015/20140305

Guerin, C., Kerr, H., \& Green, I. (2015). Supervision pedagogies: Narratives from the field. Teaching in Higher Education, 20(1), 107-118. https://doi.org/10.1080/13562517.2014.957271

Habermas, J. (1987). The theory of communicative action: The critique of functionalist reason. Polity.

Habermas, J. (1998). Remarks on legitimation through human rights. Philosophy and Social Criticism, 24(2/3), 157-171.

Harzing, A. W. (2007). Publish or perish. https://harzing.com/resources/publish-or-perish

Herman, C. (2017). Looking back at doctoral education in South Africa. Studies in Higher Education, 42(8), 1437-1454.

Hugo, W. (2009). Spiralling reference: A case study of apprenticeship into an academic community of practice. South African Journal of Higher Education, 23(4), 703-721.

King, M. L. (2016). The art of joint supervision of graduate students: What advice should we give supervisors? [Paper presentation]. 12th Quality in Postgraduate Research Conference, National Wine Centre, Adelaide, 20-22 April. https://lo.unisa.edu.au/pluginfile.php/1090717/mod resource/content/1/King\%202016.pdf

Lagemann, E. C. (1997). Contested terrain: A history of education research in the United States, 18901990. Educational Researcher, 26(9), 5-17.

Lahenius, K., \& Ikävalko, H. (2014). Joint supervision practices in doctoral education - A student experience. Journal of Further and Higher Education, 38(3), 427-446.

Lee, A. (2008). How are doctoral students supervised? Concepts of doctoral research supervision. Studies in Higher Education, 33(3), 267-281.

Lee, A. (2012). Successful research supervision: Advising students doing research. Routledge.

Leonard, D. (2001). A women's guide to doctoral studies. Open University Press.

Lessing, A. C. (2011). The role of the supervisor in the supervisory process. South African Journal of Higher Education, 25(5), 921-936.

Manathunga, C. (2012). 'Team' supervision: New positioning in doctoral education pedagogies. In Lee, A. \& Danby, S. (Eds). Reshaping doctoral education: International approaches and pedagogies (pp. 42-55). Routledge.

Manathunga, C. (2014). Intercultural postgraduate supervision: Reimagining time, place and knowledge. Routledge.

Manyike, T. V. (2017). Postgraduate supervision at an open distance e-learning institution in South Africa. South African Journal of Education, 37(2). Art. \# 1354, 11 pages, https://doi.org/10.15700/saje.v37n2a1354

McCallin, A., \& Nayar, S. (2012). Postgraduate research supervision: A critical review of current practice. Teaching in Higher Education, 17(1), 63-74. 
Patrick NGULUBE. Postgraduate supervision practices in education research and the creation of opportunities for knowledge sharing

PROBLEMS

OF EDUCATION IN THE $21^{\text {st }}$ CENTURY Vol. 79, No. 2, 2021

270

Mouton, J. (2001). How to succeed in your masters and doctoral studies. A South African guide and resource book. Van Schaik.

Mouton, J., Boshoff, N., \& James, M. (2015). A survey of doctoral supervisors in South Africa. South African Journal of Higher Education, 29(2), 1-22.

National Planning Commission. (2011). National Development Plan: Vision for 2030. Government Printing Works.

Ngulube, P. (2020). Theory and theorising in information science scholarship. In P. Ngulube (Ed.), Handbook of research on connecting research methods for information science research (pp.1839). IGI Global.

Nonaka, I \& Takeuchi, H. 1995. The knowledge creating company: How Japanese companies create the dynamics of innovation. Oxford University Press.

Nonaka, I, Toyama, R., \& Konno, N. (2000). SECI, ba and leadership: A unified model of dynamic knowledge creation. Long Range Planning, 33(1), 5-34.

Olmos-López, P. \& Sunderland, J. (2017). Doctoral supervisors' and supervisees' responses to cosupervision. Journal of Further and Higher Education, 41(6), 727-740.

Paul, P., Olson, J. K. \& Gul, R. B. (2014). Co-supervision of doctoral students: Enhancing the learning experience. The International Journal of Nursing Education Scholarship, 11(1), 31-38.

Phillips, E. M., \& Pugh, D. S. (1994). How to get a PhD: A handbook for students and their supervisors. Open University Press.

Pole, C. (1998). Joint supervision and the PhD: Safety net or panacea? Assessment \& Evaluation in Higher Education, 23(3), 259-271.

Robertson, M. J. (2017). Team modes and power: Supervision of doctoral students. Higher Education Research \& Development, 36(2), 358-371.

Scott, P. (2015). Higher education, the public good and public interest. In Filippakou, O. \& Williams, G. (Eds). Higher education as a public good: Critical perspectives on theory, policy and practice (pp. 41-58). Peter Lang.

Severinsson, E. (2012). Research supervision: Supervisory style, research-related tasks, importance, and quality - Part 1. Journal of Nursing Management, 20(2), 215-223.

Stansbury, M. C. (2002). Problem statements in seven LIS journals: An application of the Hernon/ Metoyer-Duran attributes. Library and Information Science Research, 24(2), 157-168. https://doi.org/doi:10.1016/S0740-8188(02)00110-X

Taylor, S., \& Beasley, N. (2005). A handbook for doctoral supervisors. Routledge.

Thomson, P., \& Walker, M. (2010). Doctoral education in context: The changing nature of the doctorate and doctoral students. In Thomson, P. \& Walker, M. (Eds.), The Routledge doctoral supervisor's companion: Supporting effective research in education and the social sciences (pp. 9-26). Routledge.

University of Edinburgh. (2017). Code of practice for supervisors and research students. http://www. docs.sasg.ed.ac.uk/academicservices/codes/copsupervisorsresearchstudents.pdf

University of Nottingham. (2006-2017). Directory of Open Access Repositories: Unisa Institutional Repository. http://www.opendoar.org/

University of South Africa. (n.d.). College of Education. http://www.unisa.ac.za/sites/corporate/default/ Colleges/Education

University of South Africa. (2017). Procedures for master's and doctoral degrees. http://www.unisa.ac.za/ sites/corporate/default/Colleges/Graduate-Studies/M-\&-D-policy-and-procedure-documents

Van Biljon, J. A., \& De Villiers, M. R. (2013). Multiplicity in supervision models: The supervisor's perspective. South African Journal of Higher Education, 27(6), 1443-1463.

Watts, J. H. (2010). Team supervision of the doctorate: Managing roles, relationships and contradictions. Teaching in Higher Education, 15(3), 335-339.

Weber, R. P. (1990). Basic content analysis (2nd ed.). Sage.

Wilkinson, A., Van Jaarsveldt, D., Grimsley, E., \& Seoka, L. (2016). Research trends in higher education studies at master's and doctoral level: 'Interdisciplinarity' and postgraduate supervision. In Fourie-Malherbe, M., Albertyn, R., Aitchison, C. \& Bitzer, E. (Eds.), Postgraduate supervision: Future foci for the knowledge society (pp. 349-363). SUN MeDIA.

Wisker, G. (2012). The good supervisor: Supervising postgraduate and undergraduate research for doctoral theses and dissertations (2nd ed). Red Globe Press. 
PROBLEMS

OF EDUCATION

IN THE $21^{\text {st }}$ CENTURY Vol. 79, No. 2, 2021

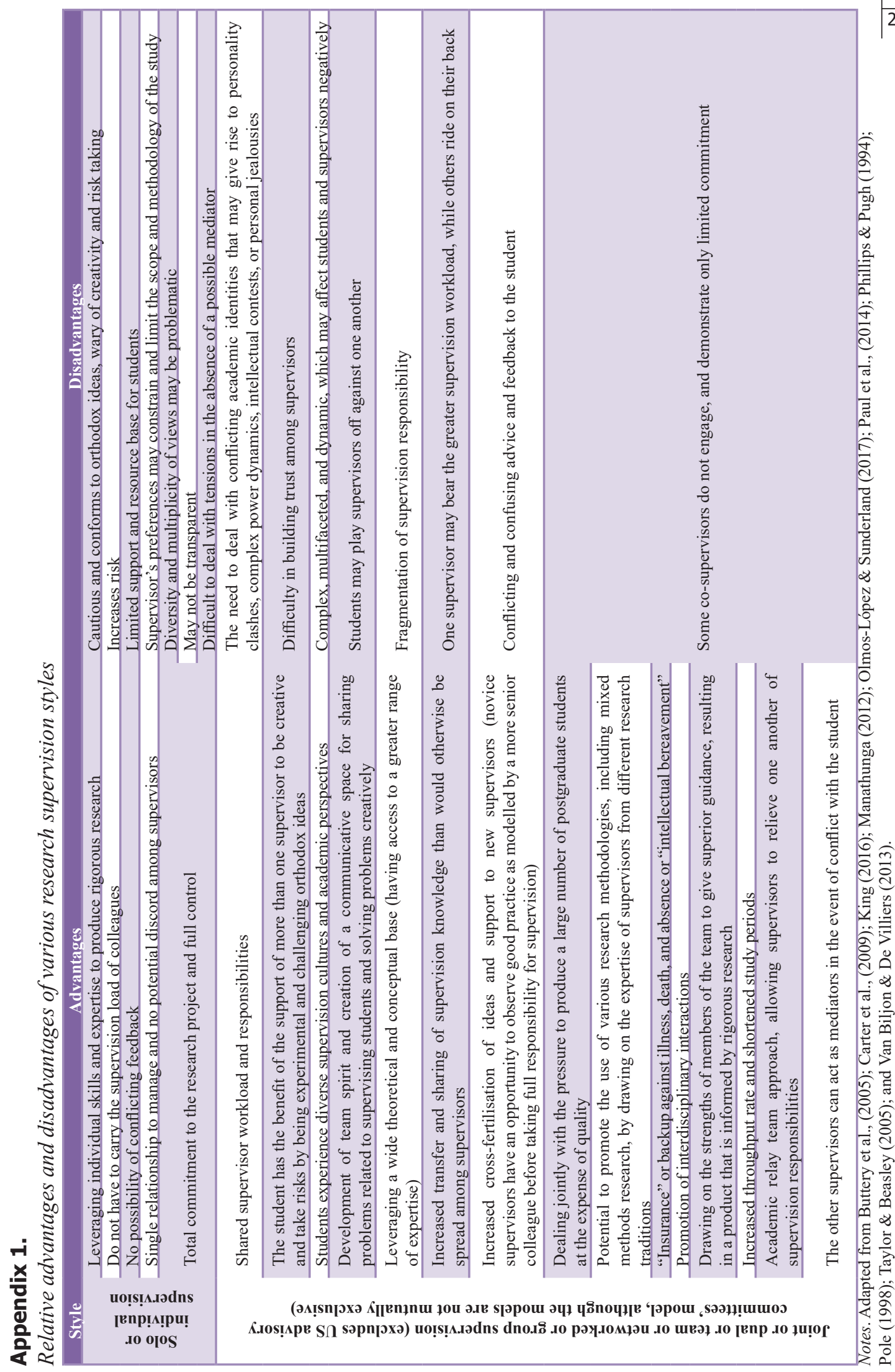


Patrick NGULUBE. Postgraduate supervision practices in education research and the creation of opportunities for knowledge sharing

PROBLEMS

OF EDUCATION

IN THE $21^{\text {st }}$ CENTURY

Vol. 79, No. 2, 2021

Received: September 23, 2020

Accepted: March 10, 2021

Cite as: Ngulube, P. (2021). Postgraduate supervision practices in education research and the creation of opportunities for knowledge sharing. Problems of Education in the $21^{\text {st }}$ Century, 79(2), 255-272. https://doi.org/10.33225/pec/21.79.255

Patrick Ngulube

$\mathrm{PhD}$, Director, University of South Africa, School of Interdisciplinary Research and Graduate Studies, PO Box 293, 0003, UNISA, Pretoria, South Africa.

E-mail: ngulup@unisa.ac.za

Website: http://www.unisa.ac.za/sites/corporate/default/Colleges/Graduate-

Studies/

ORCID: https://orcid.org/0000-0002-7676-3931 